
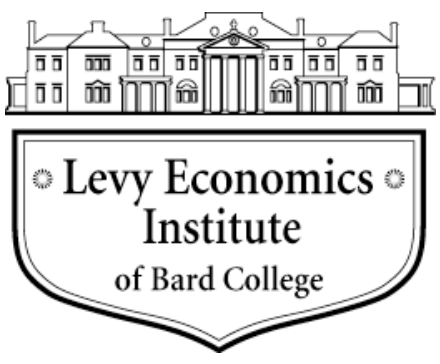

Working Paper No. 856

\title{
Redistribution in the Age of Austerity: Evidence from Europe, 2006-13*
}

by

\author{
Markus P. A. Schneider \\ University of Denver \\ Stephen Kinsella \\ University of Limerick \\ Antoine Godin \\ Kingston University
}

November 2015

*Correspondence: markus.schneider@du.edu; stephen.kinsella@ul.ie; antoine.godin@ul.ie

The Levy Economics Institute Working Paper Collection presents research in progress by Levy Institute scholars and conference participants. The purpose of the series is to disseminate ideas to and elicit comments from academics and professionals.

Levy Economics Institute of Bard College, founded in 1986, is a nonprofit, nonpartisan, independently funded research organization devoted to public service. Through scholarship and economic research it generates viable, effective public policy responses to important economic problems that profoundly affect the quality of life in the United States and abroad.

Levy Economics Institute

P.O. Box 5000

Annandale-on-Hudson, NY 12504-5000

http://www.levyinstitute.org

Copyright (C) Levy Economics Institute 2015 All rights reserved 


\begin{abstract}
We examine the relationship between changes in a country's public sector fiscal position and inequality at the top and bottom of the income distribution during the age of austerity (2006-13). We use a parametric Lorenz curve model and Gini-like indices of inequality as our measures to assess distributional changes. Based on the EU's Statistics on Income and Living Conditions SLIC and International Monetary Fund data for 12 European countries, we find that more severe adjustments to the cyclically adjusted primary balance (i.e., more austerity) are associated with a more unequal distribution of income driven by rising inequality at the top. The data also weakly suggest a decrease in inequality at the bottom. The distributional impact of austerity measures reflects the reliance on regressive policies, and likely produces increased incentives for rent seeking while reducing incentives for workers to increase productivity.
\end{abstract}

Keywords: Inequality; Austerity; Europe; Fiscal Policy; Lorenz Curve

JEL Classifications: D31, D63, E62, E65, H6 


\section{INTRODUCTION}

We add further detail to who gains and who loses based on their position in the income distribution as a result of austerity policies that most European governments turned to as a remedy to the economic fallout of the global financial crisis of 2008. Specifically, we show that austerity between 2006 and 2013 increased inequality by fattening the tail of the income distribution while possibly reducing inequality at the bottom of the income distribution. These changes are inconsistent with the position that freeing markets increases the incentives for the majority of the population to optimally participate in their national economies. They are, however, consistent with the position that austerity measures redistribute income from the bottom to the top from workers to owners of assets.

Bougrine (2012) and Peet (2011) argue that the turn towards austerity as a guiding principle for fiscal policy by governments of all political leanings is part of a general neoliberal policy regime defined by:

$[\mathrm{P}]$ artly withdrawing the state from demand management ... re-intensifying state intervention on the side of finance capital, through deregulation, privatization and de-unionization; weakening social democratic policies, like state provision of health and welfare benefits, student grants, income supplements and pension funds and "liberalization" of entire economies, as with open-border trade policies. (Peet, 2011, 388)

The exact combination of policy changes adopted depends on the structure and political leanings of the government in power, although there is surprisingly little deviation from this general policy theme post-1980 regardless of ideological orientation of the elected government. More relevant to the period we study, it is clear the explicit policy changes pushed for by the advocates of fiscal consolidation involved some combination of reducing the size of the welfare state, privatization, and liberalization. The argument behind this is invariably that government intervention distorts private incentives and freeing markets will result in efficiency gains.

The same argument is used to defend increasingly unequal distributions of incomes. More inequality increases private incentives and, via free markets, leads to efficient outcomes (Mankiw, 2013). But a close examination of the case for a neoliberal policy agenda or the argument that rising inequality is not a concern quickly reveals problems. Whether one focuses on the implausible assumptions that Robert Solow (in Solow et al., 2014) points out in his response to Mankiw (Mankiw, 2013), the lack of empirical support (summarized by Bougrine, 2012; Peet, 2011), or missing macroeconomic consistency (see Zezza, 2012), neither austerity in the later 2000s nor the broader neoliberal policy agenda appear to perform well by their own defenders' 
criteria. $^{1}$

In this context, we look at the distributional changes across countries during a particularly intense period of policy agreement when austerity-demonstrated fiscal responsibility that was believed to attract investors to such an extent that any contractionary effects would be offset - swept into vogue across Europe. As Zezza (2012) clarifies, these remedies were sold to policymakers and the public to cure ills supposedly caused by bloated welfare states when in fact they were caused by the financial crisis that spread globally from the US in 2008. Further, they were exactly the wrong remedies even on their own terms, as many economists have argued. Rather than cite the litany of critiques, we simply show the familiar figure based on IMF data showing no evidence that structural budget adjustments lead to growth (figure 1).

Figure 1: Growth vs. Structural Balance Adjustments

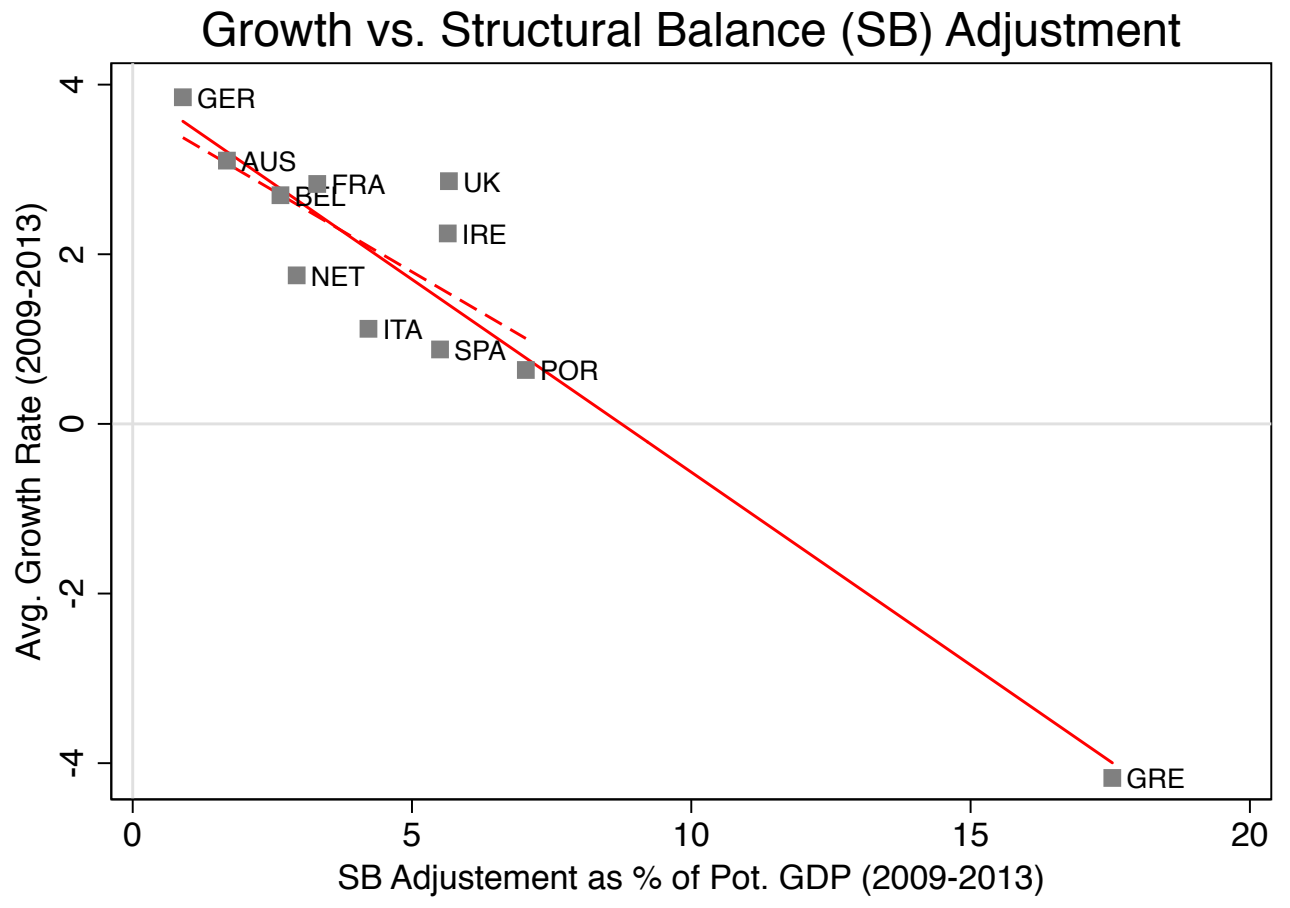

Note: The negative relationship between growth and total SB adjustment as a \% of potential output. This relationship is highly significant whether Greece is included or not (fitted trends shown for both cases).

The reforms pushed for in the name of austerity fit the neoliberal agenda well: focused on cuts to the public sector and privatization, reductions in the social safety net spending and reductions in worker security (especially via cuts to pension programs), and general attacks on

$1 \quad$ Inequality has increased (Atkinson, Piketty, and Saez, 2011) since the late 1970s, but growth has not. Rather, the gains from growth have not been shared with large swaths of the population in many developing countries while the business cycle has become more volatile as social safety nets have been dismantled. 
labor bargaining power (see table 1). Especially in the peripheral countries, revenue was raised using regressive taxation: sales and excise taxes, value-added taxes (VATs), and property taxes were increased, while increases to corporate taxes or capital gains taxes saw much spottier adoption (see table 2). The general distributional impact of fiscal consolidation made up of these policy changes is unsurprisingly to increase inequality (see the empirical findings reviewed by Schaltegger and Weder, 2014).

Table 1: Reforms to Expenditures by Country, 2009-2012

\begin{tabular}{|c|c|c|c|c|c|c|}
\hline Country & $\begin{array}{l}\text { Public } \\
\text { Wage } \\
\text { Freeze/ } \\
\text { Reduction }\end{array}$ & $\begin{array}{l}\text { Control } \\
\text { Size of } \\
\text { Civil } \\
\text { Service }\end{array}$ & $\begin{array}{l}\text { Savings } \\
\text { from } \\
\text { Pensions }\end{array}$ & $\begin{array}{l}\text { Savings } \\
\text { from } \\
\text { Health } \\
\text { Care }\end{array}$ & $\begin{array}{l}\text { Reduction } \\
\text { of Other } \\
\text { Social } \\
\text { Benefits }\end{array}$ & $\begin{array}{l}\text { Reduction } \\
\text { in Public } \\
\text { Investment }\end{array}$ \\
\hline France & & $x$ & $x$ & $x$ & & \\
\hline Germany & & & & & $x$ & \\
\hline Greece & $x$ & $\times$ & $x$ & $x$ & $x$ & $x$ \\
\hline Ireland & $\times$ & $\times$ & $\times$ & $\times$ & $\times$ & $x$ \\
\hline Italy & $x$ & $\times$ & $x$ & $\times$ & $x$ & $x$ \\
\hline Portugal & $x$ & $\times$ & $x$ & $x$ & $x$ & $x$ \\
\hline Spain & $x$ & $\times$ & $x$ & $x$ & $x$ & $x$ \\
\hline $\begin{array}{l}\text { United } \\
\text { Kingdom }\end{array}$ & $\times$ & $\times$ & $\times$ & $x$ & $x$ & $x$ \\
\hline
\end{tabular}

Source: Table 4 of International Monetary Fund (2012)

Table 2: Reforms to Revenue Sources by Country, 2009-2012

\begin{tabular}{lllllllll}
\hline Country & Incr. & Incr. & Incr. & Incr. & Incr. & Incr. & Incr. & Better \\
& Pers. & Corp. & Capital & Soc. & VAT or & Excise & Prop. & Tax \\
& Income & Income & Gains & Sec. & Sales & Tax & Tax & Compliance \\
& Tax & Tax & Tax & Contr. & Tax & & & \\
\hline France & $\times$ & $\times$ & & $\times$ & $\times$ & $\times$ & & \\
Germany & & $\times$ & & & & & & \\
Greece & $\times$ & & & $\times$ & $\times$ & $\times$ & $\times$ & $\times$ \\
Ireland & $\times$ & & $\times$ & & $\times$ & $\times$ & $\times$ & $\times$ \\
Italy & $\times$ & $\times$ & $\times$ & $\times$ & $\times$ & $\times$ & $\times$ & $\times$ \\
Portugal & $\times$ & $\times$ & $\times$ & & $\times$ & $\times$ & $\times$ & $\times$ \\
Spain & $\times$ & $\times$ & $\times$ & $\times$ & $\times$ & $\times$ & $\times$ & $\times$ \\
United & $\times$ & & $\times$ & $\times$ & $\times$ & $\times$ & & $\times$ \\
Kingdom & & & & & & & & \\
\hline
\end{tabular}

Source: Table 4 of International Monetary Fund (2012) 
The extent to which these agenda items were implemented depended greatly on the position in the European economy and the country's fiscal position. ${ }^{2}$ Europe's largest economy, Germany, which also ran a primary surplus during the later 2000s was able to commit to very little austerity and delayed implementation of much of what it committed to. France also resisted many of the more aggressive changes despite continual bad press about its fiscal position. Smaller economies of countries considered to be peripheral-like Spain, Ireland, and Greecewere less able to resist calls for reform and implemented much harsher austerity measures. The only counterexample to this characterization in our sample is the United Kingdom, where harsh austerity measures were adopted despite all, with severe consequences for its economy and population (Ginn, 2013).

Our concern is the differential impact of austerity measures on the distribution of income across European countries. To this end, we employ the two Gini-like indices proposed by Jantzen and Volpert (2012) that differentiate inequality at the top from inequality at the bottom of the distribution. Since Zezza (2012) specifically shows that the turn towards austerity implies a redistribution from workers to asset owners - from the bottom majority of the distribution to the top minority - our expectation would be that the positive relationship between fiscal consolidation in the name of austerity and inequality is driven by increasing inequality at the top. We not only find this to be the case, but also uncover weak evidence that austerity decreases inequality at the bottom.

Instead of liberalization leading to greater incentives for the majority of a population, our results imply that the incentives for most people are actually reduced while only the incentives for the elite at the very top increase. In so far as top incomes reflect rent-seeking (Gordon and Dew-Becker, 2007; Stiglitz, 2014), austerity appears to incentivize misbehavior (especially in financial markets, as argued by Stiglitz, 2012) while reducing the incentives for workers to increase their productivity.

\section{METHODOLOGY}

We explore the relationship between austerity policies and distributional changes using a panel data analysis of the changes in inequality overall, at the bottom, and at the top over the period 2006 to 2013. While all 12 countries in our sample saw on average worsening structural deficits until 2008, and there was a surprising consensus across political and national borders that austerity was necessary, implementations across countries varied in their timing, composition, and severity. Figure 2 shows the average cyclically adjusted primary balance (CAPB) across countries in our sample, and compares that average to the series for Ireland, Germany, Greece,

$2 \quad$ Schaltegger and Weder (2014) also show that the composition of the government matters and that coalition governments tend to mitigate the undesirable distributional impact better than either left-leaning or rightleaning governments. 
and Spain. Until 2008, Ireland and Greece slid towards worsening structural deficits, but both sharply turned that trend around in 2008 and 2009, respectively - at great costs to their economies, as seen in figure 1. Spain, which had been producing a primary surplus as late as 2007, slipped into a deficit position and also made adjustments by 2009. Germany was running a structural surplus for almost the entire period thanks to its persistent trade surplus.

Figure 2: CAPB for Key Countries, 2006-2014

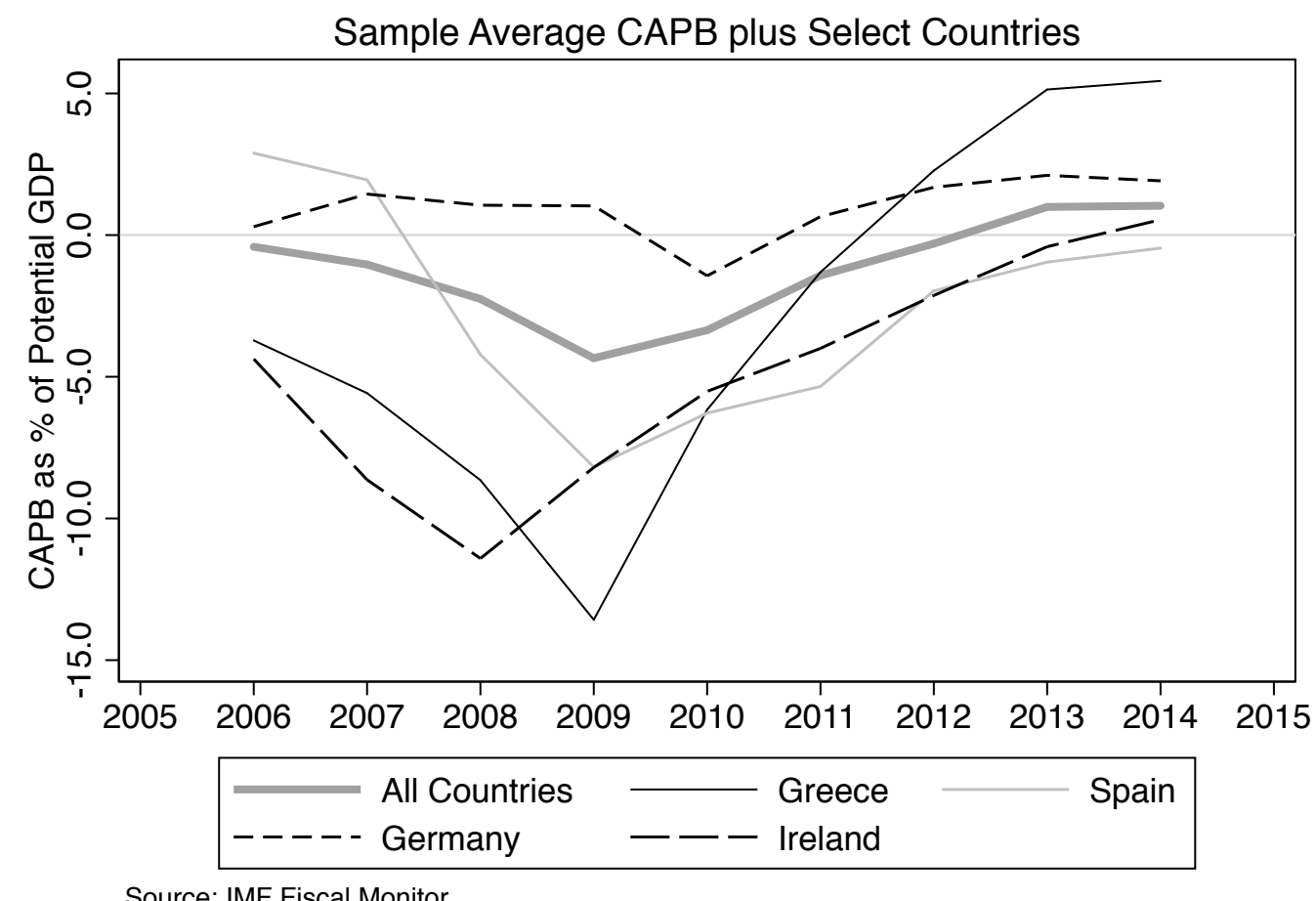

Looking at the sample of European countries as a panel over seven years and allowing for fixed effects permits us to tease out what the distributional impact of fiscal adjustments in the name of austerity were while controlling for differences in the commitment and timing of such policy packages. The dependent variables in our analysis are the Gini coefficient as a measure of inequality overall as well as Gini-like indices for inequality at the bottom and at the top of the distribution, respectively, allowing us to not only comment on the general distributional impact of austerity, but also on what part of a country's distribution of income appears to bear the brunt of the impact. The two Gini-like indices of inequality that capture inequality at the top and the bottom were proposed by Jantzen and Volpert (2012). This methodology is based on a parametric Lorenz curve model that was also described by Sarabia, Castillo, and Slottje (1999), and was fruitfully applied to US tax data by Schneider and Tavani (2015) to show a more nuanced picture of the evolution of inequality from 1921 to 2012. 


\subsection{Three Ginis}

The parametric Lorenz curve model given by equation (1) has three useful features: Sarabia, Castillo, and Slottje (1999) spell out strict criteria for Lorenz dominance based on the specific parameterization; it fits actual income data very well (e.g., in our analysis, the $R^{2}$ is greater than 0.999 for all countries and all years); and Jantzen and Volpert (2012) develop two Gini-like indices based on it.

$$
L(x ; p, q)=x^{p}\left(1-(1-x)^{q}\right)
$$

The fitted Lorenz curve can be used to calculate the Gini, $G$, given by equation (2), to capture an overall degree of inequality - where $\Gamma()$ is the Gamma function - as well as the degree of inequality at the bottom, $G_{0}$, and at the top, $G_{1}$, given by equations (3) and (4), respectively. ${ }^{3}$ These Gini-like indices are based on the degree of asymptotic self-similarity in the left and right tails of the distribution.

$$
\begin{gathered}
G=1-\frac{2}{p+1}+2 \frac{\Gamma(p+1) \Gamma(q+1)}{\Gamma(p+q+2)} \\
G_{0}=\frac{3 p}{p+2} \\
G_{1}=\frac{1-q}{1+q}
\end{gathered}
$$

Right self-similarity is a well-known phenomena associated with a power-law distribution for high incomes. It suggests that the top 10 percent of income earners capture as much of total income as the top 1 percent capture of the top decile's share, etc. The parameter $q$ captures the degree of right self-similarity, and $G_{1}$ is strictly decreasing in $q$. Inequality at the bottom is somewhat less intuitive, though the self-similarity reasoning behind it is the same as for the upper tail. ${ }^{4} G_{0}$ is a strictly increasing function of the parameter $p$ that captures the degree of left self-similarity.

In so far as inequality reflects an incentive structure for individual behavior, we suggest that it is inequality at the bottom that is most associated with increasing rewards for hard work. For one, the bottom of the distribution covers the majority of the population and thus reflects the incentive structure relevant to most people. Second, most movements within the

$3 \quad$ Note that our formulation of $G_{0}$ differs slightly from Jantzen and Volpert's (2012) so that it takes a value between 0 and 1.

4 Via e-mail, Klaus Volpert likened it to a buffet: everyone waiting to eat was split into two equal-sized groups, and group allowed to eat first takes more than half of what is available. The second group is again split in half and self-similarity implies that the half of the second group that gets to eat next takes the same percentage of what was left on the table by the first group as the first group took of the total. 
income distribution are from one quintile to either neighboring quintile, and high inequality at the bottom implies that such local moves up yield relatively big rewards in terms of extra share in total income going to the household able to make it. ${ }^{5}$ Conversely, a lack of inequality at the bottom means that the vast majority of households have no real incentives to move up, because increases in productivity through education, training, or hard work reap only small additional rewards. The share of the pie going to the bottom four quintiles - dominated by households whose main source of income is from labor - is fixed and divided relatively equally.

By contrast, inequality at the top reflects an incentive structure that applies only to a small elite of income earners. Worse, if suspicions are born out that a substantial portion of these incomes reflect rent-seeking, then more inequality at the top actually implies increased incentives to misbehave (Stiglitz, 2014). This is undesirable on many grounds, not the least of which is that rent-seeking implies net economic inefficiency. If the policy agenda is motivated by economic efficiency and taping the potential of markets, then surely the desired result of policy is to increase inequality at the bottom but limit inequality at the top. ${ }^{6}$ Looking at all three indices - $G, G_{0}$, and $G_{1}$-allows us to relate the degree of austerity imposed across countries to overall inequality as well as which portion of a country's distribution was affected. We can also use this to make some judgments about the welfare impacts of the distributional changes, and to compare these results to the desired policy outcomes.

\subsection{Analysis}

We take a very straightforward approach to test for a potential correlation between the degree to which austerity measures were implemented and the effect on distribution. The base model simply regresses the percent change in the inequality index against the percent change in a country's CAPB, as shown in equation (5).

$$
\triangle I N E Q U_{i t}=\beta_{0}+\sum_{i=1}^{12} \delta_{i} D_{i}+\sum_{i=1}^{7} \delta_{t} D_{t}+\beta_{1} \Delta C A B P_{i t}+\beta_{2} \Delta g_{i(t-1)}+u_{i t}
$$

We also control for changes in countries' growth rates $(g)$, which are affected by structural adjustments and likely affect the distribution of income. To avoid the obvious endogeneity with growth, we use the lagged change in the growth rate. The estimation is an ordinary least squares panel data estimation of the parameters while controlling for country and time fixed effects (using dummies $D_{i}$ and $D_{t}$, respectively). Standard errors are assumed to be clustered by country. For robustness, we also estimated the model using generalized least squares (GLS)

$5 \quad$ Higher inequality at the bottom also means that those left behind receive a smaller share of total income. Whether or not this is socially acceptable depends on the effectiveness and cost of the social safety net for protecting the most vulnerable.

6 Something we already know has not been achieved in the "neoliberal era" post 1980. 
and various error processes, but the ordinary least squares (OLS) estimates are shown in the paper so that we can report values for $R^{2}$. Key GLS results are included in the appendix.

The data for our analysis comes from the Statistics on Income and Living Conditions (SILC) database, from which we extracted decile pre-tax income shares for 12 countries (Austria, Belgium, France, Germany, Greece, Italy, Ireland, Luxembourg, Netherlands, Portugal, Spain, and the United Kingdom) over the study period. This data was augmented with the top 5 percent's income share available through the World Top Incomes database (Alvaredo et al., 2014) for some countries in some years, giving us Lorenz curve coordinates for the deciles plus the 95th percentile. The parameters $p$ and $q$ in equation (1) were estimated using Stata's nl estimation command, and the inequality indices appearing as the dependent variables in our panel estimations were calculated according to equations (2), (3), and (4).

The data for structural balance (SB) adjustments from 2009 to 2013 (used for figure 1) and CAPB comes from the IMF's April 2014 FiscalMonitor report (International Monetary Fund, 2014). We have continuous observations from 2006 through 2013 for all countries except Ireland, which is missing distributional data for 2013 in SLIC. Hence, we have an unbalanced panel of 12 countries over seven years with one missing observation to give us $n=83$.

\section{RESULTS}

What we find is that there appears to be a statistically significant and robust association between positive changes in CAPB and an increase in inequality as indicated by regressions (1) and (2) in table 3, and are consistent with the comparable findings by Schaltegger and Weder (2014) and others summarized therein. The positive association between deficit reduction (or surplus increase) and inequality is driven by associated increases in inequality at the top of the distribution as indicated by regressions (4) and (5) in which the percentage change in $G_{1}$ is the dependent variable. These results are robust to the exclusion of Greece, which might be seen as an outlier in terms of how much of an adjustment it has made in CAPB (see table 5 in the appendix). ${ }^{7}$ In fact, regression (4) indicates a semi-elasticity of approximately one so that a one percentage-point change in CAPB (as percent of potential GDP) corresponds to a one percent increase in $G_{1}$.

Changes in inequality at the bottom appear to largely to reflect business cycle effects, although there is weak evidence of fiscal consolidation decreasing $G_{0}$. The coefficient on $\triangle C A P B$ in regression (3) is not statistically significant, but its magnitude and sign are notable. Hence, austerity may have some incentive-reducing impacts at the bottom of the income distribution, or at least there is no evidence of it increasing the incentives for higher productivity among the

$7 \quad$ The results also hold up for the obvious balanced panels constructed by omitting either Ireland or the 2013 observations (see tables 6 and 7 in the appendix). 
Table 3: Panel Regression Results

\begin{tabular}{|c|c|c|c|c|c|}
\hline \multirow[t]{2}{*}{ Dependent Variable: } & \multicolumn{2}{|c|}{ Gini } & $G_{0}$ & \multicolumn{2}{|c|}{$G_{1}$} \\
\hline & (1) & $(2)$ & $(3)$ & $(4)$ & $(5)$ \\
\hline$\triangle C A P B$ & $\begin{array}{c}0.363^{* * *} \\
(0.0965)\end{array}$ & $\begin{array}{c}0.303^{* * *} \\
(0.0806)\end{array}$ & $\begin{array}{l}-0.440 \\
(0.273)\end{array}$ & $\begin{array}{l}1.096^{* * *} \\
(0.351)\end{array}$ & $\begin{array}{c}0.800^{* *} \\
(0.264)\end{array}$ \\
\hline$\Delta g_{t-1}$ & $\begin{array}{c}-0.237^{*} \\
(0.108)\end{array}$ & $\begin{array}{c}0.0585 \\
(0.0884)\end{array}$ & $\begin{array}{l}-0.906^{* *} \\
(0.312)\end{array}$ & $\begin{array}{c}0.132 \\
(0.384)\end{array}$ & $\begin{array}{c}0.358^{*} \\
(0.193)\end{array}$ \\
\hline Constant & $\begin{array}{c}3.41^{*} \\
(1.848)\end{array}$ & $\begin{array}{c}0.558 \\
(0.312)\end{array}$ & $\begin{array}{l}9.93^{* * *} \\
(2.73)\end{array}$ & $\begin{array}{c}0.301 \\
(4.65)\end{array}$ & $\begin{array}{c}-1.410^{*} \\
(0.689)\end{array}$ \\
\hline Country Fixed Effects & Yes*** & Yes*** & $\mathrm{Yes}^{* * *}$ & Yes*** & Yes*** \\
\hline Time Fixed Effects & Yes & No & $\mathrm{Yes}^{* *}$ & Yes* & No \\
\hline$R^{2}$ & 0.178 & 0.128 & 0.287 & 0.239 & 0.137 \\
\hline
\end{tabular}

Statistical significance at 1 percent, 5 percent, and 10 percent is indicated by ${ }^{* * *},{ }^{* *}$, and $*$, respectively; standard errors shown in parenthesis.

vast majority of the population. ${ }^{8}$

Unlike Dollar, Kleineberg, and Kraay (2015), we do find a correlation between lagged changes in the growth rate and distributional changes in our panel. It appears that faster growth is associated with decreased inequality next period - especially less inequality at the bottom of the distribution, as indicated by regression (3).

\subsection{Intuition \& Welfare Implications}

Atkinson (1970) pointed out that certain changes in the distribution of income of a countrychanges that resulted in the new Lorenz curve lying entirely below the original curve-implied a net loss in social welfare for any level of inequality aversion assuming mean income remained the same. Shorrocks (1983) extended this reasoning for situations when mean income did not remain constant by suggesting rescaling the vertical axis of the Lorenz curve using the mean income per capita so that it showed the cumulative share of total income in real terms. In theorem 2, Shorrocks (1983) spelled out general conditions to establish a welfare ranking for observed income distributions based on general assumptions for an implied social welfare function. Dollar, Kleineberg, and Kraay (2015) offer a related analysis by taking five-year windows and then asking how much per capita income would have had to change for the new generalized Lorenz curve a la Schorrocks not to lie below the old curve given the actual distributional changes. Hence, increased inequality requires compensating growth.

Based on the data used for this study, we can look at two countries that imposed harsh austerity measures and use the insights provided by Shorrocks (1983) to speculate about the

8 The GLS estimations shown in the appendix actually suggest a statistically significant negative coefficient on $\triangle C A P B$. 
welfare implications. First, consider Ireland (see figure 3). The Lorenz curve in 2012 is strictly below that of 2009, suggesting a welfare loss due to inequality. However, the Lorenz curve scaled by real GDP per capita - referred to as the generalized Lorenz curve by Shorrocks (1983) shows an upward shift and the generalized curve for 2012 curve lies almost entirely above the 2009 curve. For Ireland, the gains from GDP growth more than offset the welfare losses due to rising inequality.

\section{Figure 3: Lorenz and Generalized Lorenz Curves for Ireland}

\section{Distribution of Income 2009 vs. 2012 for Ireland}
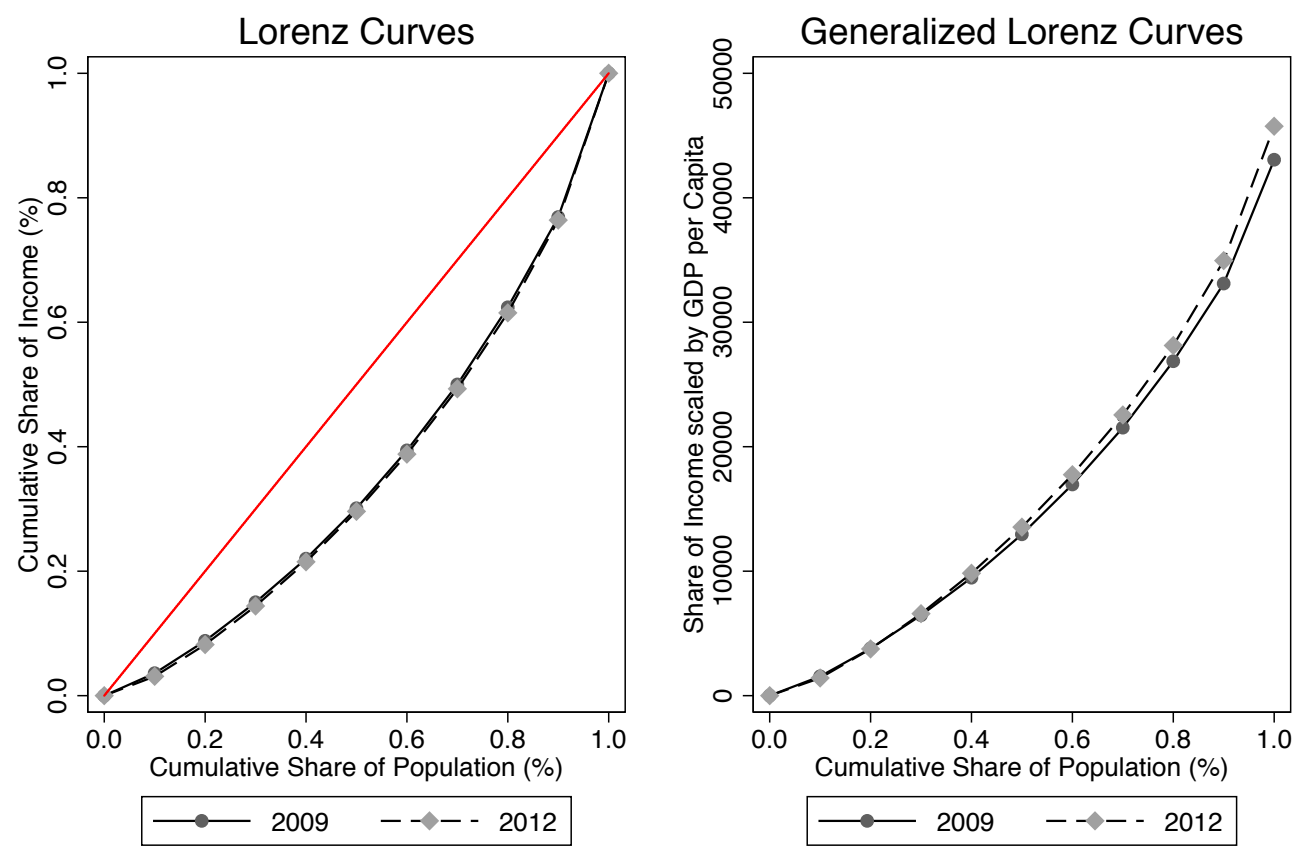

Spain's experience is similar to Ireland's: inequality rose, but there was also modest growth from 2009 to 2012, and the 2012 generalized Lorenz curve (not shown) crosses the 2009 curve, so that the net welfare implications are ambiguous unless a specific degree of inequality aversion is specified. We do not want to suggest, however, that rising inequality is the price for the gains from growth or that Ireland could have only achieved those gains by submitting to harsh austerity. Our analysis does not allow us to establish that sort of causality, and most of the literature does not indicate that this proposition holds (Bougrine, 2012; Zezza, 2012; Dollar, Kleineberg, and Kraay, 2015). What we can show is another relevant example: Greece.

As indicated in figure 2, Greece imposed even more severe austerity measures than Ireland. Tables 1 and 2 also show that the policy mix was similar for both Greece and Ireland, although Ireland did raise the capital gains tax while Greece relied exclusively on regressive revenue measures. The consequences for Greece are shown in figure 4: both the Lorenz curve and the generalized Lorenz curve for 2012 lie entirely below their 2009 counterparts. Very telling is 
that the 2012 Lorenz curve shifted down entirely because of what happened at the bottom of the curve, suggesting that the share of income going to the bottom 70 percent of the Greek population decreased. On top of that, Greece saw growth collapse, so that the Greek population was much worse off in 2012 than in 2009 both because of economic contraction and inequalityincreasing redistribution.

\section{Figure 4: Lorenz and Generalized Lorenz Curves for Greece}

\section{Distribution of Income 2009 vs. 2012 for Greece}
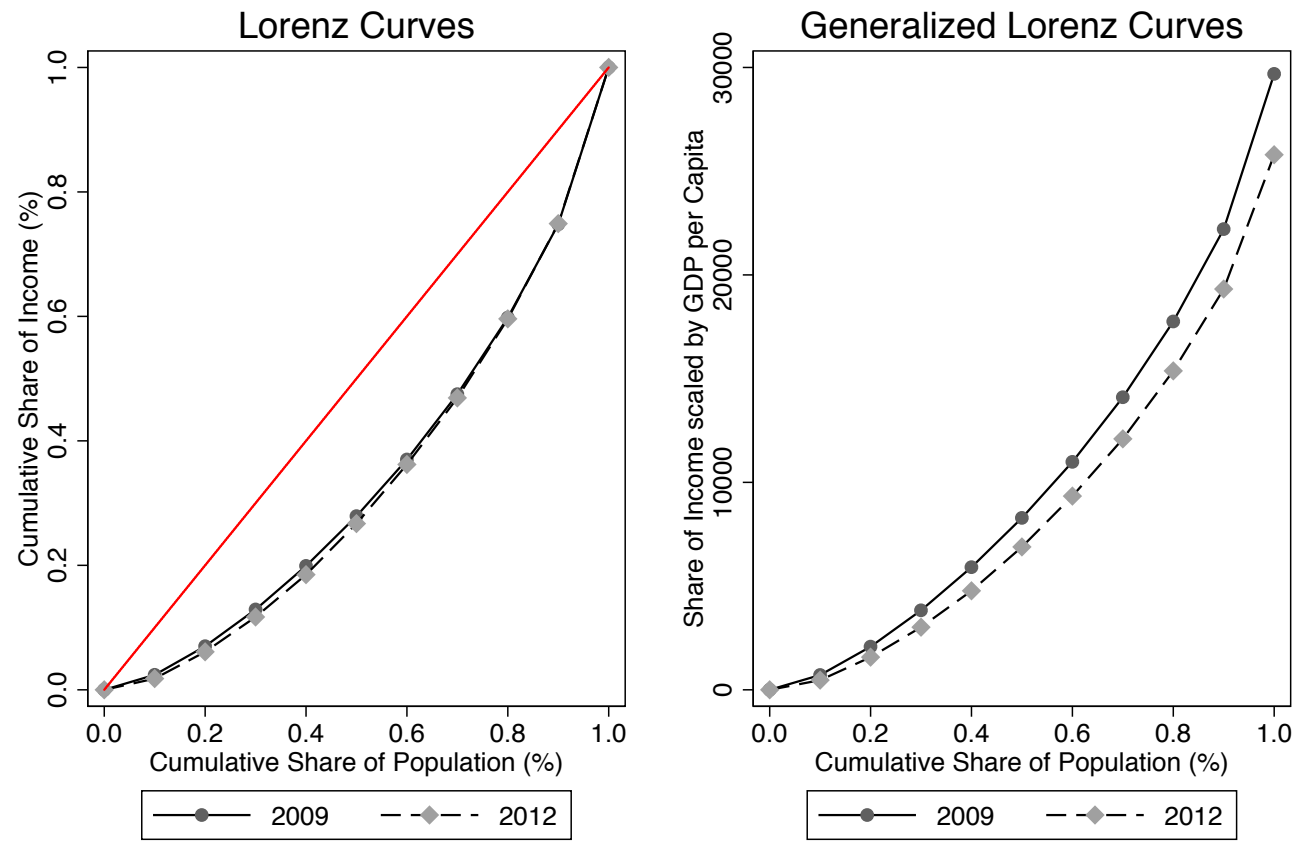

Germany's experience of decreasing inequality plus strong gains from growth in this period provides a strong contrast to the experience of Ireland, Greece, and Spain. For Germany, the 2012 Lorenz curve lies entirely above the 2009 curve (see figure 5). In addition, Germany saw strong GDP growth after 2010 so that the German population experienced a strong welfare improvement due both to improved distribution of income and growth. For several reasons, including the fact that it was running a primary budget surplus, Germany was not under pressure to implement austerity measures, and the modest measures it committed had delayed implementation dates.

\section{CONCLUSION}

We find that countries that made larger fiscal adjustments in the name of austerity in the period 2006 to 2013 also saw larger increases in inequality driven by an increase in inequality at the top, and possibly decreased inequality at the bottom. Whatever reasons where given for the 


\section{Figure 5: Lorenz and Generalized Lorenz Curves for Germany}

\section{Distribution of Income 2009 vs. 2012 for Germany}
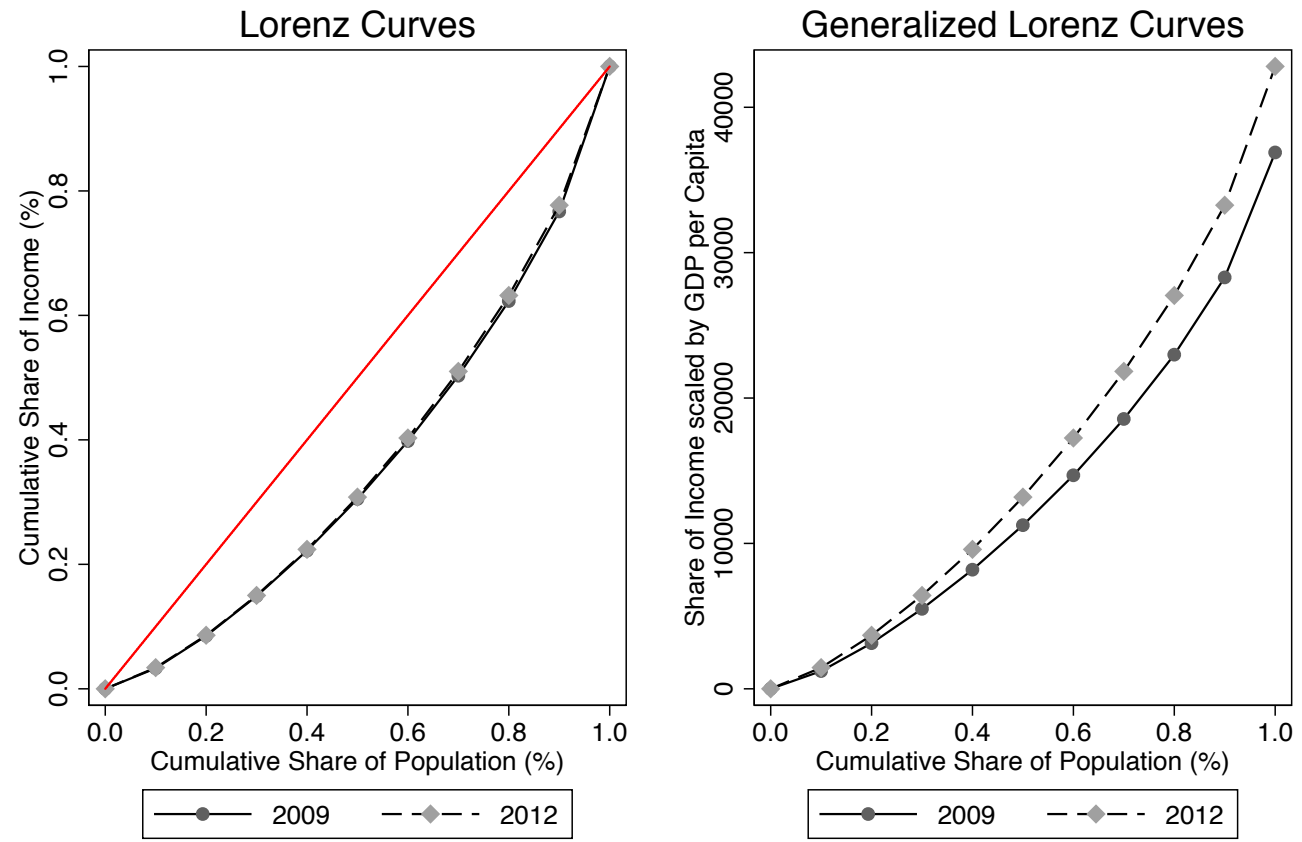

adoption of austerity measures in many European countries, their impact was regressive across the board. Surely, this will only embolden the critics of austerity who have long suspected that it really represented policy on behalf of the elites at the cost of workers (Bougrine, 2012; Peet, 2011; Zezza, 2012).

In so far as inequality at the top provides an incentive for rent-seeking and other misbehavior, those incentives have been increased in the name of fiscal responsibility. Our results also suggest that inequality at the bottom may have decreased in the face of bigger fiscal adjustments, though this effect is not statistically significant despite its notable magnitude. The implication of decreased inequality at the bottom when budgets are tightened is that the incentives for workers actually worsened.

It is hardly surprising that higher taxes and less security should have this effect. More importantly, it means that the push for austerity in the name of markets and growth not only failed to bring about growth, but actually resulted in distorting incentives across the income spectrum in exactly the opposite direction from what they should be to ensure future marketdriven growth!

The cases of Ireland, Greece, Germany, and Spain illustrate the sensitivity of these conclusions to country-specific circumstances and the role of local implementations of austerity. 


\section{REFERENCES}

Alvaredo, F., A. B. Atkinson, T. Piketty, and E. Saez (2014). The world top incomes database. Accessed December 1, 2014: http://topincomes.g-mond.parisschoolofeconomics.eu/.

Atkinson, A. B. (1970). On the measurement of inequality. Journal of Economic Theory 2(3), $244-263$.

Atkinson, A. B., T. Piketty, and E. Saez (2011). Top incomes in the long run of history. Journal of Economic Literature 49(1), 3-71.

Bougrine, H. (2012). Fiscal austerity, the great recession and the rise of new dictatorships. Review of Keynesian Economics 1(1), 109-125.

Dollar, D., T. Kleineberg, and A. Kraay (2015). Growth, inequality, and social welfare: Crosscountry evidence. Economic Policy 30(82), 335-377.

European Commission (2014). Statistics on income and living conditions (silc). Accessed December 1, 2014: http://epp.eurostat.ec.europa.eu/portal/page/portal/ income_social_inclusion_living_conditions/data/database.

Ginn, J. (2013). Austerity, inequality and politics. RASP - Research on Ageing and Social Policy 1(1), 28-53.

Gordon, R. J. and I. Dew-Becker (2007). Selected issues in the rise of income inequality. Brookings Paper on Economic Activity 2007, 169-190.

International Monetary Fund (April 2014). IMF Fiscal Monitor - Public Expenditure Reform: Making Difficult Choices. Accessed February 21, 2015: http://www.imf.org/external/pubs/ft/fm/2014/01/fmindex.htm.

International Monetary Fund (October 2012). IMF Fiscal Monitor - Taking Stock: A Progress Report on Fiscal Adjustment. Accessed February 21, 2015: http://www.imf.org/external/pubs/ft/fm/2014/01/fmindex.htm.

Jantzen, R. T. and K. Volpert (2012). On the mathematics of income inequality: Splitting the gini index in two. The American Mathematical Monthly 119(10), 824-837.

Mankiw, N. G. (2013). Defending the one percent. The Journal of Economic Perspectives 27(3), $21-34$.

Peet, R. (2011). Inequality, crisis and austerity in finance capitalism. Cambridge Journal of Regions, Economy, and Society 4, 383-399.

Sarabia, J.-M., E. Castillo, and D. J. Slottje (1999). An ordered family of Lorenz curves. Journal of Econometrics 91(1), 43-60. 
Schaltegger, C. A. and M. Weder (2014). Austerity, inequality and politics. European Journal of Political Economy 35, 1-22.

Schneider, M. P. A. and D. Tavani (2015). Tale of Two Ginis in the US, 1921 - 2012. Levy Institute Working Paper 826. http://www.levyinstitute.org/publications/tale-of-two-ginisin-the-united-states-1921-2012.

Shorrocks, A. F. (1983). Ranking income distributions. Economica 50(197), 3-17.

Solow, R., N. G. Mankiw, R. V. Burkhauser, and J. Larrimore (2014). The one percent. The Journal of Economic Perspectives 28(1), 243-247.

Stiglitz, J. E. (2012). The Price of Inequality. W. W. Norton \& Co.

Stiglitz, J. E. (2014). New theoretical perspectives on the distribution of income and wealth among individuals. forthcoming in Inequality and Growth: Patterns and Policy, vol. 1.

Zezza, G. (2012). The impact of fiscal austerity in the eurozone. Review of Keynesian Economics 1(1), 37-54. 


\section{APPENDIX}

\section{GLS Estimates}

The GLS estimated coefficients are shown in table 4. The odd models - (GLS 1), (GLS 3), and (GLS 5) - allow for heteroskedastic errors, while the even models also allow a panel-specific autoregressive process in the errors. These GLS estimations should take care of concerns of reverse causation whereby the errors should not be assumed to be independent from the regressors (specifically $\triangle C A P B$ ).

Table 4: GLS Regression Results

\begin{tabular}{|c|c|c|c|c|c|c|}
\hline \multirow[t]{2}{*}{ Dependent Variable: } & \multicolumn{2}{|c|}{ Gini } & \multicolumn{2}{|c|}{$G_{0}$} & \multicolumn{2}{|c|}{$G_{1}$} \\
\hline & $($ GLS 1) & (GLS 2) & (GLS 3) & (GLS 4) & (GLS 5) & (GLS 6) \\
\hline$\triangle C A P B$ & $\begin{array}{c}0.315^{* *} \\
(0.146)\end{array}$ & $\begin{array}{l}0.461^{* * *} \\
(0.103)\end{array}$ & $\begin{array}{l}-0.615^{* *} \\
(0.253)\end{array}$ & $\begin{array}{l}-0.465^{* *} \\
(0.221)\end{array}$ & $\begin{array}{l}1.05^{* * *} \\
(0.34)\end{array}$ & $\begin{array}{l}1.11^{* * *} \\
(0.29)\end{array}$ \\
\hline$\Delta g_{t-1}$ & $\begin{array}{l}-0.221 \\
(0.145)\end{array}$ & $\begin{array}{l}-0.206^{* *} \\
(0.083)\end{array}$ & $\begin{array}{l}-1.13^{* * *} \\
(0.274)\end{array}$ & $\begin{array}{l}-1.09 * * * \\
(0.235)\end{array}$ & $\begin{array}{c}0.372 \\
(0.40)\end{array}$ & $\begin{array}{c}0.369 \\
(0.18)\end{array}$ \\
\hline Constant & $\begin{array}{l}3.48^{* *} \\
(1.60)\end{array}$ & $\begin{array}{l}3.92^{* * *} \\
(1.11)\end{array}$ & $\begin{array}{l}11.70^{* * *} \\
(3.57)\end{array}$ & $\begin{array}{l}11.50^{* * *} \\
(2.51)\end{array}$ & $\begin{array}{l}-1.62 \\
(4.00)\end{array}$ & $\begin{array}{l}-1.25 \\
(2.86)\end{array}$ \\
\hline Country Fixed Effects & Yes & Yes*** & Yes & Yes*** & Yes & $\mathrm{Yes}^{* *}$ \\
\hline Time Fixed Effects & Yes & Yes*** & Yes*** & Yes*** & Yes & Yes* \\
\hline
\end{tabular}

Note that the coefficients are basically unaffected by these changes in specification (and compared to those reported in table 3), but that standard error estimates and statistical significance are affected. Specifically, the GLS results would support the claim that positive adjustments in CAPB lead to a decrease in $G_{0}$, and that this is a statistically significant result. 


\section{Robustness to Omission of Greece, Ireland, or 2013}

The following tables present the OLS estimates when Greece, Ireland, or observations for 2013 are omitted. Greece is omitted because it has made by far the biggest structural balance adjustments and we want to rule out that this is driving the results. Omission of Ireland or 2013 provide two balanced panel estimations. We can also use these balanced panels to do a further GLS estimation allowing for heteroskedastic and correlated errors (without or with lags in the error terms), but this did not affect the results (not shown). Note that the coefficient on $\triangle C A P B$ is significant at 10 percent when Greece is omitted, further supporting our implicit claim that the effect of austerity of inequality at the bottom is economically important.

Table 5: Panel Regression Results (without Greece, $\mathrm{N}=73$ )

\begin{tabular}{lcc|ccc}
\hline Dependent Variable: & \multicolumn{2}{c}{ Gini } & \multicolumn{2}{c}{$G_{0}$} & \multicolumn{2}{c}{$G_{1}$} \\
& $(1)$ & $(2)$ & $(3)$ & $(4)$ & $(5)$ \\
$\Delta C A P B$ & $0.395^{* *}$ & $0.293^{* *}$ & $-0.574^{*}$ & $1.275^{* *}$ & $0.946^{* *}$ \\
& $(0.140)$ & $(0.106)$ & $(0.317)$ & $(0.439)$ & $(0.308)$ \\
$\Delta g_{t-1}$ & -0.289 & 0.0702 & -0.587 & -0.347 & 0.349 \\
& $(0.239)$ & $(0.1035)$ & $(0.641)$ & $(0.603)$ & $(0.219)$ \\
Constant & 3.63 & 0.520 & 7.53 & 3.53 & $-1.410^{*}$ \\
& $(2.33)$ & $(0.360)$ & $(4.89)$ & $(6.26)$ & $(0.776)$ \\
\hline Country Fixed Effects & Yes*** & Yes** & Yes*** & Yes*** & Yes*** \\
Time Fixed Effects & Yes & No & Yes* & Yes** & No \\
\hline$R^{2}$ & 0.178 & 0.121 & 0.264 & 0.261 & 0.139 \\
\hline
\end{tabular}

Statistical significance at 1 percent, 5 percent, and 10 percent is indicated by $* * *, * *$, and ${ }^{*}$, respectively; standard errors shown in parenthesis.

Table 6: Balanced Panel Results (without Ireland, $\mathbf{N}=77$ )

\begin{tabular}{|c|c|c|c|c|c|}
\hline \multirow[t]{2}{*}{ Dependent Variable: } & \multicolumn{2}{|c|}{ Gini } & $G_{0}$ & \multicolumn{2}{|c|}{$\overline{G_{1}}$} \\
\hline & (1) & $(2)$ & (3) & $(4)$ & $(5)$ \\
\hline$\triangle C A P B$ & $\begin{array}{c}0.377^{* *} \\
(0.1256)\end{array}$ & $\begin{array}{c}0.288^{* * *} \\
(0.0850)\end{array}$ & $\begin{array}{l}-0.334 \\
(0.257)\end{array}$ & $\begin{array}{c}1.089^{* *} \\
(0.447)\end{array}$ & $\begin{array}{c}0.767^{* *} \\
(0.281)\end{array}$ \\
\hline$\Delta g_{t-1}$ & $\begin{array}{l}-0.244^{*} \\
(0.119)\end{array}$ & $\begin{array}{c}0.1115 \\
(0.0803)\end{array}$ & $\begin{array}{l}-0.885^{* *} \\
(0.349)\end{array}$ & $\begin{array}{c}0.09116 \\
(0.434)\end{array}$ & $\begin{array}{c}0.437^{* *} \\
(0.194)\end{array}$ \\
\hline Constant & $\begin{array}{c}3.41 \\
(1.959)\end{array}$ & $\begin{array}{c}0.377 \\
(0.284)\end{array}$ & $\begin{array}{l}9.24^{* * *} \\
(2.80)\end{array}$ & $\begin{array}{c}0.785 \\
(4.92)\end{array}$ & $\begin{array}{l}-1.678^{* *} \\
(0.694)\end{array}$ \\
\hline Country Fixed Effects & $\mathrm{Yes}^{* * *}$ & Yes*** & Yes $^{* * *}$ & $\mathrm{Yes}^{* * *}$ & Yes $^{* * *}$ \\
\hline Time Fixed Effects & Yes & No & Yes** & Yes & No \\
\hline$R^{2}$ & 0.186 & 0.129 & 0.259 & 0.237 & 0.141 \\
\hline
\end{tabular}

Statistical significance at 1 percent, 5 percent, and 10 percent is indicated by $* * *, * *$, and ${ }^{*}$, respectively; standard errors shown in parenthesis. 
Table 7: Balanced Panel Results (without 2013, $\mathrm{N}=72$ )

\begin{tabular}{|c|c|c|c|c|c|}
\hline \multirow[t]{2}{*}{ Dependent Variable: } & \multicolumn{2}{|c|}{ Gini } & $G_{0}$ & \multicolumn{2}{|c|}{$G_{1}$} \\
\hline & (1) & $(2)$ & $(3)$ & (4) & $(5)$ \\
\hline$\triangle C A P B$ & $\begin{array}{l}0.456^{* * *} \\
(0.128)\end{array}$ & $\begin{array}{c}0.368^{* * *} \\
(0.0812)\end{array}$ & $\begin{array}{c}-0.399 \\
(0.279)\end{array}$ & $\begin{array}{c}1.229^{* *} \\
(0.401)\end{array}$ & $\begin{array}{l}0.823^{* * *} \\
(0.266)\end{array}$ \\
\hline$\Delta g_{t-1}$ & $\begin{array}{l}-0.226 \\
(0.135)\end{array}$ & $\begin{array}{c}0.0708 \\
(0.0916)\end{array}$ & $\begin{array}{l}-1.094^{* * *} \\
(0.330)\end{array}$ & $\begin{array}{c}0.329 \\
(0.421)\end{array}$ & $\begin{array}{c}0.451^{*} \\
(0.228)\end{array}$ \\
\hline Constant & $\begin{array}{c}3.86 \\
(2.208)\end{array}$ & $\begin{array}{l}1.075^{* * *} \\
(0.330)\end{array}$ & $\begin{array}{l}11.03^{* * *} \\
(2.50)\end{array}$ & $\begin{array}{c}0.186 \\
(4.95)\end{array}$ & $\begin{array}{l}-0.768 \\
(0.820)\end{array}$ \\
\hline Country Fixed Effects & Yes*** & $\mathrm{Yes}^{* * *}$ & $\mathrm{Yes}^{* *}$ & $\mathrm{Yes}^{* * *}$ & Yes*** \\
\hline Time Fixed Effects & Yes & No & Yes** & Yes* & No \\
\hline$R^{2}$ & 0.204 & 0.144 & 0.338 & 0.259 & 0.154 \\
\hline
\end{tabular}

Statistical significance at 1 percent, 5 percent, and 10 percent is indicated by $* * *, * *$, and $*$, respectively; standard errors shown in parenthesis. 